Utah State University

DigitalCommons@USU

CWEL Publications

2014

\title{
Growth of Bella Bluegrass Compared to a Standard KBG Blend and Tall Fescue
}

Paul Johnson

Utah State University

Xin Dai

Roberrto Gurel

Follow this and additional works at: https://digitalcommons.usu.edu/cwel_pubs

Part of the Plant Sciences Commons

\section{Recommended Citation}

Johnson, Paul; Dai, Xin; and Gurel, Roberrto, "Growth of Bella Bluegrass Compared to a Standard KBG Blend and Tall Fescue" (2014). CWEL Publications. Paper 93.

https://digitalcommons.usu.edu/cwel_pubs/93

This Article is brought to you for free and open access by DigitalCommons@USU. It has been accepted for inclusion in CWEL Publications by an authorized administrator of DigitalCommons@USU. For more information, please contact digitalcommons@usu.edu.

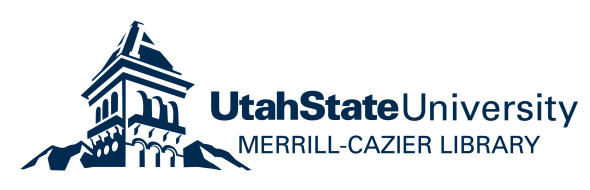




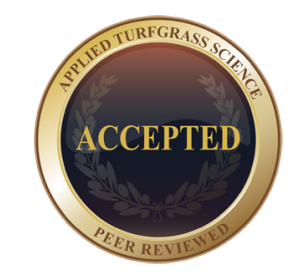

\title{
Growth of Bella Bluegrass Compared to a Standard KBG Blend and Tall Fescue
}

\author{
Paul G. Johnson, ${ }^{\star}$ Xin Dai, and Roberto Gurgel
}

\section{PUBLIC SUMMARY}

A goal of low-input turfgrass is to reduce mowing, thereby reducing labor, fuel, and equipment expenses. A way to meet this goal is to develop grasses that grow slower. 'Bella' Kentucky bluegrass was released by the University of Nebraska-Lincoln as slow-growing variety of bluegrass. This experiment documents slightly to significantly slower growth of 'Bella' compared to a traditional Kentucky bluegrass sod blend and tall fescue grown in the Intermountain West region of North America.

Consumers frequently seek grasses that need less mowing and fertilizer (Busey and Parker, 1992). Although turfgrasses recover from traffic by growing, many uses don't need fast growth due to minimal traffic. With this in mind, 'Bella' Kentucky bluegrass (Poa pratensis) was released by the University of Nebraska-Lincoln as a slower growing variety compared to other bluegrasses (Shearman, 2010). This study was conducted to further test if Bella bluegrass grows slower than a standard blend of bluegrass and a tall fescue variety at two mowing heights and three fertilization rates in northern Utah.

\section{PLOT DESCRIPTION, CLIMATE CONDITIONS, AND DATA COLLECTION}

The experiment was a randomized block design for the grasses and a strip-split plot design for mowing and nutrition, respectively. The grasses were (i) Bella Kentucky bluegrass; (ii) BioBlue mix-equal parts Moonlight SLT, Prosperity, P-105, and Bedazzled Kentucky bluegrass; and (iii) BioTurf tall fescue (Festuca arundinacea)-90\% Bolero tall fescue and 10\% Monte Carlo Kentucky bluegrass, all provided by Biograss Sod (Draper, UT) and planted as sod on 11 May 2011 in North Logan, UT. Each grass entry was planted in $12 \mathrm{ft} \times 12 \mathrm{ft}$ blocks with three replications, each replication stripped with mowing heights of 2 and 3 inches mowed weekly. The soil was a Millville silt loam, pH 7.9. In 2011, the area was mowed but
Paul G. Johnson, Professor, Dep. of Plants, Soils \& Climate, Utah State Univ., Logan, UT; Xin Dai, Data Analyst, Utah Agricultural Experiment Station, Utah State Univ., Logan, UT; Roberto Gurgel, Research Executive Director, Sod Solutions, Inc., Mt. Pleasant, SC. Received 3 Mar. 2014. *Corresponding author (paul.johnson@usu.edu).

Published in Applied Turfgrass Science DOI 10.2134/ATS-2013-0018-BR

(C) 2014 American Society of Agronomy and Crop Science Society of America 5585 Guilford Rd., Madison, WI 53711

All rights reserved. No part of this periodical may be reproduced or transmitted in any form or by any means, electronic or mechanical, including photocopying, recording, or any information storage and retrieval system, without permission in writing from the publisher. Permission for printing and for reprinting the material contained herein has been obtained by the publisher. 
Table 1. Mean values for leaf height and longest leaf height over three measurements per plot, three replications, two mowing ${ }^{\dagger}$, and three fertilizer regimes ${ }^{\ddagger}$ on Bella bluegrass, a Kentucky bluegrass sod blend, and a tall fescue variety grown in North Logan, UT in 2012 and 2013.

\begin{tabular}{|c|c|c|c|c|c|c|c|c|c|c|c|}
\hline Species & $\begin{array}{c}4 \text { June } \\
2012\end{array}$ & $\begin{array}{c}25 \text { June } \\
2012\end{array}$ & $\begin{array}{c}2 \text { July } \\
2012\end{array}$ & $\begin{array}{c}27 \text { Aug. } \\
2012\end{array}$ & $\begin{array}{c}5 \text { Sept. } \\
2012\end{array}$ & $\begin{array}{c}31 \text { May } \\
2013\end{array}$ & $\begin{array}{l}7 \text { June } \\
2013\end{array}$ & $\begin{array}{l}16 \text { July } \\
2013\end{array}$ & $\begin{array}{c}23 \text { July } \\
2013\end{array}$ & $\begin{array}{c}6 \text { Sept. } \\
2013\end{array}$ & $\begin{array}{c}13 \text { Sept. } \\
2013\end{array}$ \\
\hline \multicolumn{12}{|c|}{ Average leaf height ${ }^{\S}$} \\
\hline Bella & $50 \mathrm{a}^{\text {q }}$ & $48 \mathrm{a}$ & $66 \mathrm{a}$ & $49 a$ & $52 \mathrm{a}$ & $51 \mathrm{a}$ & $50 a$ & $49 a$ & $47 \mathrm{a}$ & $51 \mathrm{a}$ & $56 a$ \\
\hline KBG & $52 \mathrm{a}$ & $51 \mathrm{a}$ & $66 \mathrm{a}$ & $56 \mathrm{~b}$ & $54 \mathrm{a}$ & $51 \mathrm{a}$ & $49 a$ & $53 \mathrm{ab}$ & $54 \mathrm{~b}$ & $69 \mathrm{~b}$ & $72 \mathrm{a}$ \\
\hline TF & $59 \mathrm{~b}$ & $56 \mathrm{~b}$ & $74 \mathrm{~b}$ & $66 c$ & $74 \mathrm{~b}$ & $57 \mathrm{a}$ & $53 a$ & $58 b$ & $59 \mathrm{c}$ & $67 \mathrm{~b}$ & $72 \mathrm{a}$ \\
\hline \multicolumn{12}{|c|}{ Longest leaf height ${ }^{\S}$} \\
\hline Bella & $64 a$ & $63 a$ & $78 \mathrm{a}$ & $60 \mathrm{a}$ & $61 a$ & $73 a$ & $71 \mathrm{a}$ & $62 \mathrm{a}$ & $63 a$ & $76 \mathrm{a}$ & $77 \mathrm{a}$ \\
\hline KBG & $69 a$ & $69 a b$ & $85 a$ & $74 \mathrm{~b}$ & $67 a$ & $74 \mathrm{a}$ & $78 \mathrm{~b}$ & $77 \mathrm{~b}$ & $82 b$ & $102 b$ & $99 \mathrm{~b}$ \\
\hline TF & $82 \mathrm{a}$ & $77 \mathrm{~b}$ & $95 \mathrm{~b}$ & $92 \mathrm{c}$ & $88 \mathrm{~b}$ & $82 \mathrm{a}$ & $87 \mathrm{c}$ & $85 \mathrm{~b}$ & $91 \mathrm{c}$ & $105 b$ & $102 \mathrm{~b}$ \\
\hline
\end{tabular}

† Mowing heights were 2 inches and 3 inches mowed weekly.

‡ Fertilizer treatments were $0.5,1.0$, and $2.0 \mathrm{lbs} \mathrm{N} / 1000 \mathrm{ft}^{2} / \mathrm{yr}$ and applied over three application dates per year.

$\S$ Average leaf height and longest leaf height was measured using a Turfcheck-II grass height gauge (Turf-Tec International, Tallahassee, FL) and a mirror to view the leaves and gauge from above. Average height was the midpoint of the many leaves viewed. Longest height was the length of the longest leaf viewed.

" Mean values followed by the same letter are not significantly different at $p>0.05$ within columns and within average height or longest height measurements.

not fertilized to equalize nitrogen status. Within these mowing heights on each of the grasses, we applied three fertilizer treatments in 2012 and 2013 making individual plots of $4 \mathrm{ft} \times 6 \mathrm{ft}$. Total nitrogen per year $(0.5,1.0$, and $2.0 \mathrm{lb} \mathrm{N} / 1000 \mathrm{ft}^{2}$ ) was split among three dates each year ( 1 June \pm 5 days, 15 July \pm 3 days, and 1 September \pm 5 days). Ammonium sulfate was dissolved in $0.3 \mathrm{~L}$ of water and evenly sprayed over each plot using a $\mathrm{CO}_{2}$ backpack research sprayer with a spray wand and one flat fan nozzle. Irrigation replaced $70 \%$ of ETo to avoid drought stress. Climatic conditions during the study were typical for the location (Utah Climate Center, 2014). Applications of imidacloprid were applied in early May of 2012 and 2013 for control of billbug (Sphenophorus spp.); however, damage was still observed during 2013 in the Bella bluegrass plots.

Growth rate was measured at 11 dates before mowing using a Turfcheck-II grass height gauge (Turf-Tec International, Tallahassee, FL) and a mirror to view the leaves and gauge from above. We recorded average height, the midpoint of the many leaves viewed, and length of the longest leaf viewed. Longest leaves may spur mowing sooner than average leaf height. Three locations within each plot were measured in areas not affected by billbug damage and averaged by plot for analysis. Data were analyzed using PROC MIXED (SAS Institute, Cary, NC [version number of software, year?]) and least squares means compared by pairwise comparisons using a $t$ test.

\section{SPECIES GROWTH TRENDS}

Throughout the study, Bella's average leaf height never exceeded the other two entries, was significantly less than that of KBG on 3 of 11 measurement dates, and significantly less than TF on 9 of 11 measurement dates (Table 1). Likewise, Bella's longest leaf height never exceeded the other two species, was significantly less than that of KBG on 6 of 11 rating dates, and significantly less than TF on 9 of 11 rating dates (Table 1). As expected, mowing height had a significant effect on leaf height, but no meaningful species $\times$ mowing height interactions. Also as expected, $\mathrm{N}$ rate yielded significant differences in growth with higher $\mathrm{N}$ rates increasing leaf measurements (data not shown); however, those effects were similar over the three grasses (infrequent and not meaningful species $\times$ fertilizer interaction). Three-way interactions of species, mowing, and fertility yielded occasional significance over the dates observed, but no meaningful trends emerged. Our interpretation is that the grasses responded similarly to the mowing heights and fertilizer treatments.

\section{CONCLUSIONS}

Although not always statistically significant, growth trends indicate that Bella bluegrass grows slower compared to the bluegrass blend used in this study and significantly slower compared to the tall fescue blend. This growth pattern was consistent across the mowing height and nitrogen fertilization regimes tested here.

\section{References}

Busey, P., and J.H. Parker. 1992. Energy conservation and efficient turfgrass maintenance. In: D.V. Waddington, R.N. Carrow, and R.C. Shearman, editors, Turfgrass. Agron. Monogr. 32. ASA, CSSA, SSSA, Madison, WI. p. 473-500.

Shearman, R.C. 2010. US Patent Application Poa pratensis L. named 'NE-KYB-05-001'. US Patent Office. US 2010/0024086 P1. Publication date: 28 Jan. 2010.

Utah Climate Center. 2014. AgWeather Network. http://climate.usurf.usu. edu/agweather.php?station_num $=424$ (accessed 10 July 2014). Utah State Univ., Logan, UT. 